\title{
A CHALLENGE TO TRAVEL LITERATURE AND STEREOTYPES BY TWO TURKISH WOMEN: ZEYNEB HANOUM AND SELMA EKREM
}

\author{
OZLEM EZER \\ York University (Canada)
}

The recent critical attention devoted to women's travel writing performs a logical transition from the ongoing focus on autobiography, representations of memory and multiculturalism as well as the issue of the Subject. Travel extends the inward direction of autobiographical experience to consider the journey outward. Regardless of the journey's motive (study, emigration, flight, conversion or domination) a journey changes both the country visited and the self that travels. I would like to introduce the travel accounts by two Turkish women written in English in the early $20^{\text {th }}$ century from a feminist and critical perspective and deconstruct the Turkish women image of the West through their travel accounts ${ }^{1}$.

The travel accounts by Western women in the early $20^{\text {th }}$ century and earlier were not the most uncommon texts referred to in the feminist interpretations of travel literature by women. However, it has been extremely difficult to obtain any autobiographical accounts when one conducts a research on the other way around, namely Eastern women travelers who traveled to Europe and North America. The two Turkish women travelers' accounts presented here make this article exceptional in this sense. Both travel accounts are first-hand texts written by the Turkish women themselves in English, so no translation is needed. Both texts are (although easy to read in terms of English and structure like many other travelogues) full of complicated signs waiting to be analyzed related to these two upper-class Turkish women's self-definition, their use of language constructed for the Western audience an evaluation of the Turkish family life, customs and traditions, and their Western woman image. That is where the theories and illustrations of image/identity formation as well as

1. I am well aware of the risks and drawbacks of using broadly and relatively defined terms such as West/East, however due to limited space, I won't be able to discuss their associations and definitions extensively. 
the most recent alternative criticism to orientalist discourse will be presented. Additionally, both sides of the coin will be shown, not just the orientalist products but also the Turkish women's own prejudices and partial comments towards the West as well. They can easily be labeled as an Oriental's "othering" without overlooking the fact that despite all the different misinterpretations and aspects from both sides, a common feminine language can be put forward after analyzing the texts written by the women mentioned here.

Based on Irvin C. Schick's argument, it is important to state the obvious reciprocal question which lies in the background of this discussion: could not other societies including those of the West, be viewed equally as exotic and engendered by the people, the writers and the elite of the Middle East? Western power and its self-appointed duty to speak on behalf of other cultures have some indirect claims such as knowing the "truth" about them and also some justifications on Western expansions ${ }^{2}$. What I try to achieve by presenting two Turkish women's impressions is in a way applying Schick's theory in their writings since the West was the "exotic» for these Turkish women. Before going further with these analyses, it is useful to include the summaries of the travel accounts and life stories of the two women which are inextricably woven together.

The first book, A Turkish Woman's European Impressions, is written by Zeyneb Hanoum, who was an expatriate with her sister between the years 19061912. The book was written in English and printed in 1913 in London when she was probably still in her twenties. The other book is called Unveiled-The Autobiography of A Turkish Girl written again originally in English by Selma Ekrem and printed in 1930 in New York. The book covers the years 1902-1923 and it had four prints successively from 1930 to 1936 in the United States and was highly praised by the critics at the time. Ekrem presents us some vivid observations and impressions of a sinking empire and the accounts of a series of compulsory journeys caused by her father's political position and her family past. Selma Ekrem moved to the United States in 1923, although her book Unveiled ends with her coming back to a new «modern» Turkey after a period of a deep longing. She completed her autobiography seven years after she moved to the United States, when she was only twenty-eight, when her memories were still fresh.

Zeyneb Hanoum's book is written in epistolary form, namely composed of the letters written to an English journalist woman, Grace Ellison, who is also the editor of the book. Zeyneb Hanoum who was a grown up, single, young woman shares her impressions of Europe very openly with her. She writes her impressions about countries such as France, England, Switzerland, Belgium, and Italy while at the same time sharing with Grace Ellison her experiences in Turkish culture, customs and family traditions, and making numerous comparisons. The initial point for both journeys (Zeyneb's and Selma's) is due

2. BASCI, Pelin: «The Erotic Margin», The Turkish Studies Association, 24 (2000), p. 140. 
to the political reasons and the milieu, namely the oppression and paranoia of the period during Abdulhamid the Second's reign (1842-1918). However, in Selma's case, it was her father who was charged because of the paranoia that reigned in the court trials. In Zeyneb Hanoum's case, she herself was accused because of her criticism of the sultan in her writings.

As one of the political results of Zeyneb Hanoum's rebellious character, her organization of the young-girls-only white dinner parties already drew suspicions on her. Therefore her awareness and aggressiveness is fully expressed in her letters as opposed to the more simple and naive impressions of Selma Ekrem. However, by the time Selma reached puberty and was forced to wear her first tscharshaf (veil), her tone in the book suddenly changes into a very negative and obsessive resistance against the family and status quo in general.

Zeyneb Hanoum describes the Orient as such: «The Orient is like a beautiful poem which is always sad, even its very joy is sadness» $»^{3}$. I would also like to question her descriptions since I think that some of her passages carry an orientalist tone similar to her Westerner peers. The content of the book enables me to evaluate the text in both ways. While she is traveling around Europe, she comments on the countries' traditions, the details of daily life and the different values. Zeyneb Hanoum's comparisons of Turkey to Europe become more and more biased against Europe as she starts justifying almost each and every Turkish custom and the Turkish life style as a whole. I will speculate on what might be the possible reasons behind her disappointments since she did not encounter any particular negative or racist treatment that she relates in her letters. Towards the end of the book she mentions a "total lack of hospitality" in the west and concludes by saying that «it is in the west that I appreciate my country ${ }^{4}$. Another question she poses is if women are really free in the West or not. This also is one of the questions that Fatima Mernissi asks in her book Scheherazade Goes West. On the other hand, the images that the Westerners have about a Turkish woman and their comments, questions and responses to Zeyneb Hanoum are also present in the book including the female editor, Grace Ellison. These details help us out to see the different images and impressions of the "foreigner» constructed on both sides.

Julia Kristeva claims that there are two kinds of foreigners, and this separates uprooted people of all countries into two uncompromising categories. On the one hand, there are those who waste away in an agonizing struggle between what no longer is and what will never be. They are not necessarily defeatists; they often become the best of ironists. On the other hand, there are those who transcend: living neither before nor now but beyond, they are bent with a passion that will remain forever unsatisfied. This is a passion for another land,

3. Hanoum, Zeyneb: A Turkish Woman's European Impressions, London, Seeley, Service \&Co.Ltd., 1913, p. 117.

4. Ibid., p. 238.

5. Kristeva, Julia: Strangers to Ourselves, New York, Colombia University Press, 1991, p. 10. 
always a promised one. These foreigners are believers, and they sometimes ripen into skeptics ${ }^{5}$.

Kristeva's ideas contributed a great deal to explain the growing bitterness and extreme negativism of the tones two Turkish women's travel accounts, especially in Zeyneb Hanoum's case. At some point in her memoirs, she was asked the reason for her journeys while chatting with an English woman who thought that Zeyneb Hanoum was French without even asking her. Zeyneb Hanoum likens herself to Diogenes who tried to find a man. Instead she has been trying to find a free woman but has not been successful ${ }^{6}$. Even the change in the chapters' titles presents enough clues that reflect her mind: "Is this Really Freedom?», "Dreams and Realities», "Freedom's Doubtful Enchantment». In another instance, she acknowledges this "Western" and/or "European» illusion she created before she started her journeys and shares an anecdote told by her Koran teacher, which perfectly fits Kristeva's classification of the Foreigner(s):

"There was a little girl in a country of Asia Minor who believed all she heard. One day she saw a chain of mountains blue in the distance. Is that really their color she asked? Yes, they answered. She was so delighted with the answer so goes out to get a nearer view of the blue mountains. After days of walking she got to the summit of the blue mountains. Only to find grass just as can be found anywhere else. But she would not give up. A shepherd there pointed her another chain of mountains higher and farther away, and she went there until the peak, and found the same grass. She went on and on until the evening of her life. She then understood that it was the distance that lent the mountains their hue. But it was too late to go back and she perished in the cold, biting snow ${ }^{7}$.

This anecdote can be considered as a key story in Zeyneb Hanoum's letters to Grace Ellison, which in fact combines many theories of otherness and perceptions of the foreigner in one paragraph. When I reflect on the travel accounts I have read so far (which cannot all possibly be listed) one element is quite common among them: the emergence of disappointment from both sides, Western and Eastern. Since the traveler acts on the knowledge obtained from the images and the secondary sources of the past, disappointment with the place or the people is almost inevitable.

The last sentence of Zeyneb's travel accounts is also in accordance with Kristeva's theory: since Zeyneb Hanoum wastes herself away in "an agonizing struggle between what no longer is and will never be", she will remain forever unsatisfied: "Désenchantée I left Turkey, désenchantée I have left Europe. Is that role to be mine till the end of my days?» ${ }^{8}$

Selma Ekrem presents a different attitude than Zeyneb Hanoum does probably due to the fact that starting from her childhood she had to travel to different countries and live there in longer time periods than Zeyneb Hanoum

6. Hanoum, Zeyneb: Op.cit., p. 200.

7. Ibid., p. 228.

8. Ibid., p. 246. (It is an allusion to Pierre Loti's novel Disenchanted /Les Désenchantées in which she gave body to one of its main characters). 
did. Ekrem explains the main reason why she went to the States as such: « ... to be able to wear a hat in peace» ${ }^{9}$. On the contrary, Zeyneb Hanoum does not like hats at all and calls it an "absurd fashion» ${ }^{10}$.

A Western reader who reads Selma Ekrem's accounts would be very surprised with the multicultural household and the family relationships she experienced. Several languages can be heard at home since they have Greek servants and French teachers. In addition, the children attend to the Koran courses in order to acquire an appropriate religious background. Therefore, it can be inferred that the family's attitude towards education is a very cosmopolitan and sophisticated one (of course the French admiration was at a high level in Turkey at the time). At some point in their accounts both of the writers complain about this strange mixture and are aware that the great confusion they have in their minds and daily life practices are due to this type of education. Wine is served in Ekrem's family every night and interestingly she compares her aunts' responses when sitting next to each other at the table. The fact that one of her aunts is playing cards and drinking wine, whereas the other abstains from a single drop of alcohol due to her religious interpretations is a perfect example to demonstrate this confusion in a small scale of the Turkish society if the family is taken as a reflection of a society.

Another striking point to mention in a study of images in Selma Ekrem's account is her confusion in Jerusalem where they had selamlik(men-only space) and harem(women-only) for the first time: «We had never lived in such a house before, never had known a divided home ${ }^{11}$. It is significant to note this detail when one talks about the Western constructions of Turkish woman image throughout the centuries ${ }^{12}$. Ekrem's immediate explanations after her comment on harem maintain her impartiality as a writer and do not mislead the reader during a potential reconstruction of the new image about Turkey:

«In Constantinople we had not needed a harem for my father allowed mother appear before any friend of his whom she wanted to see. She had not been brought up in that narrow atmosphere where it was considered a sin to show one's face to men and to expose one's hair to casual glances in the streets. Her father was extremely liberal and she had brought to her home these liberal ideas which revolted the old heads ${ }^{13}$.

As it is quite clear from this paragraph, Selma Ekrem is not denying the facts of the Ottoman culture and practices other than her own family. However, what she is doing in her memoirs is new in the way that it challenges the

9. Ekrem, Selma: Unveiled, New York, Ives Washburn, 1930, p. 290.

10. Hanoum, Zeyneb: Op. cit., p. 66.

11. EKrem, Selma: Op. cit., p. 290.

12. For an extensive search on the issue please see ARAT, Zehra (ed.): Deconstructing images of the Turkish woman, New York, St. Martin's Press, 1998; and EVREN, Burçak (ed.): Yabancı Gezginler ve Osmanl Kadinı (Foreign Travelers and Ottoman Woman), Dilek Girgin Can., Istanbul: Milliyet Yayinlar1, 1997.

13. Ibid, p. 57. 
stereotypical narration of the Turkish women throughout centuries. Irvin C. Schick's comment deserves be underlined here, he suggests that Western power including its literature -appointed itself to speak on behalf of other cultures which produced "truths" about them. One of these "truths» is the harem. Another woman writer who is also having serious difficulties in understanding the obsession of the West with the harem is the Moroccan sociologist Fatima Mernissi. Her contribution in corrections/reconstructions of Oriental images is not only about Turkish women but women of the Muslim societies in general. A striking example from her book related to Matisse, and not to mention Picasso's harem sketches, as late as 1955, fits here as a reminder to the Western reader:

"In the 1920s, when Matisse was painting Turkish women as harem slaves in his paintings such as Odalisque with Red Trousers, Kemal Atatürk was promulgating feminist laws that granted Turkish women the right to education, the right to vote, and the right to hold public office» ${ }^{14}$.

Selma Ekrem's travel to the United States, which takes place towards the end of the book, is an intensive part full of images where she is asked so many questions about Turkish women. The ignorance of Americans about Turkey brings her very close to Zeyneb Hanoum's cynical attitude in her book. In one occasion, where Selma meets some young girls in her friend's house, such a conversation takes place:

"I would simply adore to be in a harem» one of the girls broke my cup of thoughts.

"And lie on silken cushions and eat sweets and watch the dancing of the slave girls,» another laughed. (...)

"A paradise indeed,» I sighed. "Could you tell me what is a harem? I never saw one.»

«You never saw a harem!» the girls burst out. "And you come from Turkey?»

«Yes, I come from Turkey,» I added firmly, «but I did not live in a marble palace, I did not have slaves, I did not lie on silken cushions. This harem you speak about exists only in your imagination $»^{15}$.

As can be observed from Selma's straightforward attitude towards these young American girls she meets for the first time in Washington, an ironical tone like Zeyneb Hanoum's becomes obvious. She leaves her listeners disappointed since she crushes their imaginary picture of an exotic land decorated with the soft mystery of silks, perfumes and music. She soon begins to express her criticism against America in a more professional way and starts making money by lecturing about Turkey to Americans. This experience actually becomes an example to my initial claim that there is a support and cooperation between the women of the West and Selma Ekrem, no matter how hard she may criticize them in several occasions. Ironically enough, the suggestion of giving

14. Mernissi, Fatima: Scheherazade Goes West, New York, Washington Square Press, 2001, p. 109. 15. Eкrem, Selma: Op. cit., pp. 311-312. 
lectures on Turkey comes from an American friend of hers since there were no such practices in Turkey at that time yet. By lecturing in different states about Turkish women, their daily lives and traditions, Selma Ekrem certainly contributes to a positive Turkish women image, travels and makes money as well. One and a half years later, she misses Turkey, gets homesick and describes the feeling in this way: "The American tonic had become too strong for my Eastern nerves» ${ }^{16}$. However, my quotations might be misleading without mentioning the gap between the classes of the Turkish society at that time. It is not claimed here that the constructions of the Turkish women images in the West were fictive overall. There were actually harem and selamlik sections in many houses in different regions of Turkey when Selma was taken aback with the sight of a house where men and women were to sit separately in Jerusalem. Although Selma's and Zeyneb's families constitute a different class and have different background, they are still Turkish.

Unlike Zeyneb Hanoum, Selma Ekrem becomes so happy to find out that the Kemalist revolutions are put in practice and it is normal and accepted to wear a hat now on the streets for women when she comes back to Turkey in the late 1920s. She actually writes, "Turkey was a bit of America tamed and softened by the East ${ }^{17}$. This analogy is something mostly used in a pejorative sense today whereas she meant it in a very positive way.

Zeyneb Hanoum and Selma Ekrem's disappointments and ironical criticisms about the Westerners' prejudices during their solo travels are mostly reasonable. These preconceptions are mostly the products of Western men, not the women since women are already silenced by the same system and mentality within their societies and ascribed certain roles. Besides the examples presented here, several interesting ones can be provided from Mernissi's book about this subject. It is difficult not to agree with her when she finds it strange that in the 1920s, an Oriental military man like Atatürk was dreaming of liberated women, while a man like Matisse, bred in a democracy, was dreaming of odalisques and an Islamic civilization that he confused with women's passivity ${ }^{18}$.

Transformation of the female Self during traveling and its transcription into a text cannot always result as it is aimed ${ }^{19}$. That is why/how my claim of a distinctive and supportive language among women travelers can still be maintained despite some complexities in the texts of these travel accounts that may easily be labeled as "flaws». Women travelers whose roots are originated in the Western or Eastern cultures are willing to deconstruct images, stereotypes and prejudices. This genre's complexity should not prevent its recognition and hopefully open up some contemporary debates.

16. Ibid., p. 317.

17. ERrem, Selma: Op. cit., p. 319.

18. Mernissi, Fatima: Op. cit., p. 200.

19. Milss, Sara: An Analysis of Women's Travel Writing and Colonialism, New York, Routledge, 1991, p. 36. 